\title{
ДИПЛОМАТИЯ
}

И ВОЕННЫЕ КОНФЛИКТЫ

DOI: https://doi.org/10.15688/jvolsu4.2021.1.11

UDC 94(71)

Submitted: 15.09.2019

LBC 63.3(0)6

Accepted: 23.01.2020

\section{CANADA'S PARTICIPATION \\ IN THE IMPERIAL MILITARY BODIES IN THE FIRST WORLD WAR}

\author{
Ekaterina S. Simonenko \\ Far Eastern Federal University (FEFU), Vladivostok, Russian Federation
}

\begin{abstract}
Introduction. The paper is devoted to the participation of Canada in the creation and activities of the Imperial War Cabinet and two Imperial War Conferences of 1917 and 1918 to explain the evolution of the foreign and political status of Canada as a part of the British Empire after the end of the War. Methods and materials. The paper is based on the British and Canadian Parliamentary Debates, Reports, Minutes of Proceedings and Meetings of the Imperial War Conferences 1917/1918 and the Imperial War Cabinet. To study them, it uses the method of historical criticism of sources. The author also uses the historical-genetic, comparative and the narrative methods to investigate the causes, the process of creating and activities of imperial military bodies for the unified management of the war. Analysis. The paper analyzes the reasons for the creation of imperial military organizations in the British Empire during the war. It reveals the organizational and functional differences between the two imperial military bodies: Cabinet and Conference. The author studies the activities of imperial military bodies during the war in detail, determines the role of the Canadian delegation in this process. The article analyzes the decisions of the imperial military bodies, reveals their domestic and foreign policy consequences for Dominion of Canada. Results. Canada's active participation in the creation and activities of the imperial military bodies during the First World War was one of the factors in the transformation of the Empire into the Commonwealth of Nations, the formation of its own national identity, political and foreign independence within the Empire.

Key words: Canada, British Empire, First World War, Imperial War Cabinet, Imperial War Conference, D. Lloyd George, R. Borden.

Citation. Simonenko E.S. Canada's Participation in the Imperial Military Bodies in the First World War. Vestnik Volgogradskogo gosudarstvennogo universiteta. Seriya 4. Istoriya. Regionovedenie. Mezhdunarodnye otnosheniya [Science Journal of Volgograd State University. History. Area Studies. International Relations], 2021, vol. 26, no. 1, pp. 123-132. (in Russian). DOI: https://doi.org/10.15688/jvolsu4.2021.1.11
\end{abstract}

УДК 94(71)

ББК $63.3(0) 6$
Дата поступления статьи: 15.09.2019

Дата принятия статьи: 23.01.2020

\section{УЧАСТИЕ КАНАДЫ \\ В ДЕЯТЕЛЬНОСТИ ИМПЕРСКИХ ВОЕННЫХ ОРГАНОВ В ГОДЫ ПЕРВОЙ МИРОВОЙ ВОЙНЫ}

\author{
Екатерина Сергеевна Симоненко
}

Дальневосточный федеральный университет, г. Владивосток, Российская Федерация 


\section{ДИПЛОМАТИЯ И ВОЕННЫЕ КОНФЛИКТЫ}

Аннотация. Статья посвящена изучению процесса создания и функционирования системы единого военного управления Британской империей в годы Первой мировой войны. Ключевую роль в этом процессе сыграла Канада как одно из самых влиятельных автономных образований, входивших в состав империи на правах доминиона. Реконструкция процесса участия Канады в создании и деятельности имперского военного кабинета и двух имперских военных конференций 1917 и 1918 гг. позволит объяснить эволюцию внутри- и внешнеполитического статуса Канады в составе Британской империи после окончания войны. На основе парламентских документов Канады и Великобритании, отчетов и протоколов заседаний имперских военных конференций и имперского военного кабинета анализируются причины создания имперских военных организаций в Британской империи в годы войны. Исследуется взаимная реакция британского и колониального общества на прямое участие в заседаниях британского кабинета министров представителей доминионов. Выявляются организационные и функциональные различия между двумя имперскими военными организациями: кабинетом и конференциями. Подробно изучается деятельность имперских военных организаций в годы войны, определяется роль канадской делегации в этом процессе. Анализируются решения имперских военных органов, выявляются их внутри- и внешнеполитические последствия для доминиона. В целом активное участие Канады в создании и деятельности органов единого военного управления в годы Первой мировой войны явилось одним из факторов трансформации Британской империи в Содружество наций, а также формирования канадской идентичности, ее внутри- и внешнеполитической самостоятельности в границах империи.

Ключевые слова: Канада, Британская империя, Первая мировая война, имперский военный кабинет, имперская военная конференция, Д. Ллойд Джордж, Р. Борден.

Цитирование. Симоненко Е. С. Участие Канады в деятельности имперских военных органов в годы Первой мировой войны // Вестник Волгоградского государственного университета. Серия 4, История. Регионоведение. Международные отношения. - 2021. - Т. 26, № 1. - C. 123-132. - DOI: https://doi.org/10.15688/ jvolsu4.2021.1.11

Введение. Реконструкция процесса участия Канады в общеимперских военных консультациях в годы Первой мировой войны важна для более глубокого понимания процесса становления национального самосознания канадского народа, а также эволюции внутри- и внешнеполитического статуса доминиона в составе Британской империи после окончания войны.

Методы и материалы. В работе используется историко-генетический метод, с помощью которого исследуются причины и процесс создания имперских военных органов для единого руководства войной. Сравнительный метод исторического исследования применяется для сопоставления суждений представителей британской и канадской политической элиты по вопросу расширения властных полномочий колониальных властей. Данный метод также используется для выявления различий в структуре, организации и функциях имперского военного кабинета и конференции. Описательно-повествовательный метод позволил реконструировать повестку дня, а также события, которые сопутствовали деятельности имперского военного кабинета и конференции в их хронологической последо- вательности. Наконец, для изучения содержания отчетов о дебатах в парламентах Канады и Великобритании, отчетов и протоколов заседаний имперского военного кабинета и конференций применяется метод исторической критики источников.

Анализ. Генезис идеи имперских военных консультаций. Проблема обеспечения безопасности Британской империи занимала ключевое место в стратегическом планировании Великобритании. До середины XIX в. весь комплекс обязанностей по защите зависимых территорий возлагался на метрополию. Однако осуществление наземной и морской обороны колоний требовало значительных затрат, что грозило создать дефицит бюджета. Во второй половине XIX в. на волне общественного недовольства в среде военно-политического руководства Великобритании возникла идея взаимной ответственности, что означало перераспределение части обязательств в области имперской обороны на колонии. Метрополии следовало ограничиться защитой морских коммуникаций и зависимых владений силами Королевского флота, тогда как колонии должны были обеспечивать безопасность своих сухопутных границ. 
В течение четверти века (1887-1911 гг.) изменения в организации имперской обороны были закреплены резолюциями колониальных и имперских конференций. В результате длительных дебатов были достигнуты договоренности о том, что колонии создадут местные вооруженные силы для защиты своих государственных границ, а также будут выплачивать регулярные взносы на содержание британского флота (последний пункт получил одобрение всех самоуправлявшихся колоний, за исключением Канады). Взамен метрополия соглашалась допустить представителей своих крупнейших автономных владений к участию в выработке имперской политики и стратегии. Однако до войны механизм привлечения премьер-министров доминионов не был разработан в деталях, а степень их информирования по действительно важным вопросам была минимальна. Так, в 1909 г. делегации от доминионов были приглашены на заседания имперской военной конференции, главным итогом которой стало создание комитета имперской обороны для разработки плана коллективной обороны на случай войны. В июле 1915 г. премьер-министр Канады Р. Борден посетил серию заседаний британского военного кабинета, а в 1916 г. его сменил премьер-министр Австралии У. Хьюз [4, p. 42].

Когда в 1914 г. началась война, в кругах политического руководства доминионов стала крепнуть уверенность в том, что факт присутствия колониальных контингентов в составе британских войск на европейском театре военных действий требует создания системы единого военного управления. Свое практическое воплощение эта идея получила в декабре 1916 г., когда в Великобритании к власти пришло коалиционное правительство Д. Ллойда Джорджа. Одним из пунктов его политической программы стало создание имперского консультативного органа, призванного обсуждать насущные проблемы ведения войны и условия послевоенного мира. В нем на паритетных началах должны были заседать представители метрополии и автономных владений британской короны. По замыслу властей метрополии, делегаты от доминионов должны были посещать заседания имперского военного кабинета по мере необходимости, при этом соблюдая принцип регулярности [23, p. 11-12].
Создание имперского военного кабинета. 12 декабря 1916 г. Д. Ллойд Джордж в письме, адресованном министру колоний У. Лонгу, обосновал решение пригласить делегатов от доминионов в состав британского военного кабинета. Он, в частности, писал: «...Мы должны привлечь доминионы к участию в наших военных совещаниях в гораздо более широкой мере, чем это делалось до сих пор. Они принесли огромные жертвы, но мы до сих пор не совещались с ними ни о целях войны, ни о методах ее ведения... Мы хотим получить от них больше людей. Вряд ли можно просить их о новом большом наборе, если наша просьба не будет сопровождаться одновременным приглашением приехать и обсудить наше общее положение» [2, с. 26-27].

Решение о приглашении представителей доминионов на заседания британского кабинета министров произвело двойственное впечатление на английское общество. С одной стороны, это был первый случай, когда делегаты от колоний приглашались не в консультативный, а исполнительный орган военного управления империей, что свидетельствовало о начале более тесного сотрудничества. С другой стороны, визиты Р. Бордена и У. Хьюза в 1915 и 1916 гг. носили в большей степени формальный характер. Глава канадского правительства «лишь раз присутствовал на заседании английского кабинета, когда происходило обсуждение такого второстепенного вопpoca, как борьба с контрабандой хлопком. Главная цель Р. Бордена осталась недостигнутой: он так и не смог добиться предоставления необходимой ему информации о военно-политических планах британского руководства» [1, с. 227]. После поездки в Англию глава канадского правительства вновь оказался в изоляции, получая информацию о событиях в Европе из газет. Это побудило его в конце 1915 г. поставить перед министром колоний Э. Бонаром Лоу вопрос о проведении совместных консультаций. Полученный ответ не оставлял никаких сомнений: Лондон вполне устраивала существовавшая система военного руководства. Откровенно небрежное отношение правительства Г. Асквита к канадским властям вызвало у Р. Бордена протест: «Вопрос заключается в том, - писал премьер-министр Верховному комиссару в Лондоне, - кем 
ведется война: одним Соединенным Королевством или всей империей? Если правильна вторая гипотеза, тогда почему британские государственные деятели претендуют на единоличное руководство ею?» [1, с. 239].

25 декабря 1916 г. главы всех британских автономий получили телеграммы из Лондона с предложением принять участие в работе военного кабинета [4, p. 24-25]. Многим этот шаг показался очевидным. По свидетельству современников, на тот момент истинного значения данного события не осознавали ни в самой метрополии, ни тем более в доминионах. Возможно, что его подлинный смысл первоначально был скрыт и от самих авторов этой инициативы [21, p. 218]. Выступая в Палате общин канадского парламента 22 января 1917 г., Р. Борден с воодушевлением сообщил, что в Лондоне представители доминионов будут участвовать в обсуждении актуальных вопросов ведения войны и заключения мира. Премьер-министр прекрасно понимал, что приглашение Д. Ллойд Джорджа имело под собой прагматическое основание: Канада должна была отправить на фронт как можно больше солдат, а взамен получала право участвовать в имперских консультациях. Однако он решил принять это приглашение для того, чтобы «добиться адекватного голоса в формировании имперской стратегии и политики» [3, p. 72; 4, p. 42-45]. Для некоторых канадских политиков приглашение оказалось большой неожиданностью. Так, лидер либеральной оппозиции У. Лорье заявил, что не понимает, как глава федерального правительства Канады, не будучи членом британского парламента, может присутствовать на заседаниях имперского кабинета министров [4, p. 24-25].

Несмотря на создание имперского военного кабинета, Великобритания не отказалась от проведения традиционных конференций в предвоенном формате. Между этими двумя консультативными органами наблюдались существенные различия. Во-первых, на заседаниях кабинета председательствовал глава британского правительства, а на конференции - министр по делам колоний. Во-вторых, в имперском военном кабинете обсуждались проблемы, связанные с ведением войны и заключением мира, а заседания конференции, напротив, были посвящены вопросам импер- ской политики, не связанным с войной. В-третьих, несмотря на то что заседания обоих органов проходили в обстановке секретности, в отличие от решений кабинета отдельные резолюции конференции предавались гласности [8, p. 28-29]. Наконец, самое существенное различие заключалось в том, что имперский военный кабинет являлся консультативным и одновременно исполнительным органом, формирующим политику, в то время как имперская военная конференция обладала лишь консультативными полномочиями и все ее резолюции носили рекомендательный характер. В связи с этим было решено, что для большей эффективности заседания военной конференции будут проходить параллельно с заседаниями военного кабинета.

Деятельность имперского военного кабинета и конференции в 1917 г. 12 февраля 1917 г. делегация доминиона отправилась в Лондон, чтобы принять участие в заседаниях имперского военного кабинета и конференции $[5$, p. 1526]. График работы главы канадского правительства был очень плотным. В день прибытия он дал интервью, в котором подробно охарактеризовал программу мер, предпринятых Канадой в рамках плана интеграции доминиона в коллективную оборону империи. По его словам, автономия уже отправила за границу более 300 тыс. человек, привлекла такое же количество рабочих к производству военной техники, боеприпасов и снаряжения [12, p. 2].

В разгар визита Р. Бордена в Лондон стало известно, что австралийский премьер-министр не сможет вовремя прибыть на конференцию из-за участия в парламентских выбоpax. По этой причине открытие конференции было отложено до конца марта, и канадская делегация, чтобы не терять времени даром, отправилась во Францию инспектировать свои отряды на фронте. Это была первая поездка Р. Бордена на передовую с 1915 года. В средине марта 1917 г. он вернулся в Лондон и заявил в интервью британской прессе, что он нашел «дух, физическое состояние и подготовку канадских отрядов блестящими» [5, p. 1526, 1536-1540].

Первые заседания имперского военного кабинета и конференции были назначены на 20 и 21 марта соответственно. Все последу- 
ющие заседания также должны были проводиться в разные дни, чтобы делегаты конференции могли участвовать и в работе кабинета. В обязанности делегатов входило не только посещение заседаний, но и подготовка документов по наиболее важным вопросам повестки дня, а также проведение совещаний с чиновниками различных британских министерств [19, р. 287].

По замыслу британских властей, на заседаниях имперского военного кабинета должен был применяться принцип равного статуса министров метрополии и доминионов, предполагающий, помимо всего прочего, знакомство представителей доминионов с планами ведения войны и условиями мира, носившими гриф «секретно». Скептики, активно критиковавшие курс Д. Ллойд Джорджа на сближение с доминионами, полагали, что приглашение представителей автономных владений в военный кабинет должно расцениваться не более чем знак вежливости, а обсуждение конкретной военной стратегии происходить в их отсутствие. Они также считали аномальным присутствие премьер-министров Канады или Южной Африки в ходе дискуссий по вопросам продовольственного снабжения или поставок угля на британские острова [23, p. 16]. Лорд Г. Лансдаун подытожил позицию скептиков, заявив, что «в любом случае у нас должно быть три органа - наш собственный военный кабинет, кабинет министров или его эквивалент и имперский военный кабинет» [9, p. 256].

Еще одним основанием для полемики стало наименование имперского военного кабинета. Скептики провели терминологический анализ и сделали вывод о том, что к органу, включавшему представителей нескольких государственных образований в составе империи, было неприменимо определение «кабинет». Согласно нормам конституционного права, кабинет министров мог быть отстранен от власти протестным голосованием высшего законодательного органа. Таким образом, парламент любого доминиона, несогласного с политикой имперского военного кабинета, мог проголосовать за его роспуск. Глава канадской делегации возразил, что орган, в отношении которого велись ожесточенные споры, по сути являлся «кабинетом прави- тельств» тех стран, которые в нем заседали. Решения, принятые «кабинетом шести правительств», носили коллегиальный характер, поэтому вотум недоверия должен был выноситься одновременно парламентами всех автономий, чьи министры присутствовали в его составе [22, p. 8-9].

В рамках первой сессии, длившейся с 20 марта по 2 мая 1917 г., состоялось четырнадцать заседаний имперского военного кабинета [18, p. 72]. Было принято решение, что встречи министров станут регулярными и на них будут обсуждаться актуальные проблемы имперской политики. Подтверждая тезис о том, что дальнейшее ведение войны - это коллективное обязательство, члены кабинета постановили: в случае отсутствия Д. Ллойд Джорджа функции председателя будет исполнять канадский премьер-министр [23, p. 15]. В свою очередь, Р. Борден поспешил заверить присутствующих, что все владения британской короны «единодушны в том, чтобы предпринять огромные усилия» для участия в войне, и «готовы продолжать их, насколько это возможно и необходимо» [17, p. 8-9].

Одним из главных вопросов повестки дня стала разработка новых способов наращивания численности имперских войск, которые в ближайшее время следовало отправить на фронт. По статистике, озвученной на заседании 30 марта, армия союзников насчитывала 13 млн человек против 8 млн армии центральных держав, из них «5 млн составляли русские, 2 млн итальянцы, а также румыны, бельгийцы, португальцы и другие войска сравнительно низкой боевой ценности» [12, p. 2]. Британская армия нуждалась еще как минимум в 500 тыс. солдат из колоний. Поэтому в условиях кризиса добровольной системы набора требовалось разработать новую схему отправки подкреплений союзникам. В ходе дискуссии глава канадского правительства высказал свое видение данной проблемы и пути ее решения. По его мнению, в самое ближайшее время во всех доминионах следовало ввести систему принудительной воинской службы [17, p. 9].

На заседаниях военной конференции, продолжавшихся с 21 марта по 27 апреля 1917 г., была озвучена новая концепция имперских отношений, одним из авторов которой стал 
руководитель канадской делегации. 16 апреля он выдвинул на голосование резолюцию, в которой содержалось требование по окончании войны создать британское Содружество наций, куда должны были войти все доминионы и Индия. В рамках нового имперского образования им следовало получить право самостоятельного участия во внешней политике Британской империи [6, p. 40-60; 22, p. 9]. Предложение приняли большинством голосов. В решении конференции отмечалось, что после окончания войны британский кабинет обязуется провести конституционную реформу, а Адмиралтейство - разработать новую стратегию коллективной морской обороны, в которой активная роль была отведена Канаде и ее флоту [6, p. 5]. Резолюция № IX объективно подвела черту под предшествующим этапом развития имперских отношений, зафиксировав переход автономий в очередной, высший класс политического ученичества [1, c. 248]. Она положила начало организации британского Содружества наций, которое оформилось в 1926 г., но официальное закрепление получило только в Вестминстерском статуте 1931 года.

Вторым важным вопросом, который активно обсуждался в ходе конференции, стала проблема послевоенного мирного урегулирования в Европе. Канадских делегатов интересовал вопрос собственного представительства на мирной конференции, которая должна была состояться в обозримом будущем. Однако пока было неясно, на каких условиях они могли принимать в ней участие. По предварительной информации, власти метрополии выразили желание, чтобы Р. Борден в процессе подготовки конференции находился в Лондоне, а затем сопровождал британскую делегацию в Париж [6, p. 40-60].

Работа имперского военного кабинета и конференции завершилась 2 мая «к полному удовлетворению всех сторон». Она содействовала достижению по крайней мере двух важных результатов: улучшились взаимоотношения Великобритании и доминионов, и одновременно укрепились позиции кабинета Д. Ллойд Джорджа [1, с. 248]. Еще до отъезда в Канаду Р. Борден высоко оценил результаты своей работы в имперских военных органах. По его убеждению, с их созданием началась новая эра в истории взаимоотношений между метрополией и доминионом, которая положила начало рождению нового политического образования на пространстве Британской империи - Содружества наций. Перед тем как покинуть Англию, Р. Борден написал главе британского правительства письмо, в котором выразил надежду, что участие представителей доминионов в решении имперских проблем станет обычной практикой [5, p. 1529-1530]. В свою очередь, Д. Ллойд Джордж выразил уверенность в том, что заседания имперского военного кабинета будут проводиться ежегодно [22, p. 7].

Прибыв в Канаду, премьер-министр 18 мая 1917 г. представил Палате общин подробный отчет о своем пребывании в Англии. В речи, адресованной парламентариям, Р. Борден выразил уверенность в том, что практика приглашения колониальных представителей в общеимперские консультативные органы будет активно развиваться. Он признался, что опыт, полученный в Лондоне, дал ему «ясное понимание военных проблем, колониальных обязанностей и ответственности». Поэтому до окончания войны доминион должен будет отправить на фронт в общей сложности 1 млн чел. [5, p. 1525-1530]. В тот же самый день он представил парламенту законопроект о введении конскрипции.

Деятельность имперского военного кабинета и конференции в 1918 г. В 1918 г. начался новый виток имперских консультаций. С 11 июня по 25 июля прошли заседания имперского военного кабинета, с 12 июня по 26 июля имперской военной конференции. Р. Борден отправился в Англию 26 мая в компании министров коалиционного правительства [16, p. 9]. Спустя две недели они прибыли в столицу, где приняли участие в серии встреч с британскими министрами и делегатами от доминионов. Речи главы канадского правительства, посвященные войне и имперским обязательствам, воспринимались крайне одобрительно, особенно британской прессой [20, p. 415].

К началу второй сессии стало известно о нововведениях, которые коснулись состава и принципов работы имперского военного кабинета. Было принято решение о том, что в заседаниях будут участвовать по два делегата от каждого доминиона и Индии. Для обеспечения 
непрерывной работы один из двух делегатов не ниже министерского ранга должен был постоянно находиться в Лондоне. В то же время министрам полагалось «сохранять связь» со своими доминионами и ежегодно посещать их [14, p. 4]. В дни работы имперского военного кабинета «малый» военный кабинет прекращал свою деятельность и временно переключался на обсуждение общих вопросов. Если раньше заседания кабинета проходили в атмосфере строгой секретности, то теперь его резолюции стали публиковаться в ежедневных отчетах для внутреннего пользования. Перед началом заседаний члены кабинета стали получать отпечатанный накануне план работы на предстоящий день [23, p. 18-19].

На второй сессии имперского военного кабинета дискуссия началась с обсуждения военных проблем, а затем плавно перешла на вопросы внешней политики. В ее ходе Р. Борден признался, что до созыва имперского кабинета национальный статус доминионов был ограничен «опекой» британского правительства в области внешней политики и обороны [8, p. 32-33; 23, p. 16-17]. Однако теория «опеки», на которой до сих пор строились имперские отношения, окончательно исчерпала себя и была несовместима со статусом доминионов как самостоятельных государственных образований. Идеалом для него являлось имперское Содружество объединенных наций под эгидой британской короны [1, с. 247].

В итоге кабинет принял резолюцию, где гарантировалось, что представители доминионов будут не только участвовать в определении стратегии, которой будет придерживаться Великобритания на мирной конференции. Они сами будут присутствовать на заседании Верховного военного совета союзников, запланированного на 5 июля 1918 г. в Париже [8, p. 30-31]. Одним из важнейших решений конференции 1918 г. стало создание специального имперского совета по демобилизации, где в равной степени должны были быть представлены делегаты от Соединенного Королевства и доминионов. В его компетенцию входило решение вопросов, связанных с расформированием воинских подразделений и отправкой их домой $[7$, p. $7 ; 8$, p. 41$]$.

Обе поездки главы канадского правительства и его коллег в Англию продолжались в общей сложности восемь месяцев (февраль - май 1917 г., май - август 1918 г.). Столь длительное отсутствие ключевых министров на своих постах вызвало явное недовольство в Канаде. Вскоре из Лондона и Оттавы последовали официальные объяснения. Все они сводились к тому, что британские власти не могли обойтись без помощи канадских представителей в решении вопросов войны и мира. При этом рабочие заседания проходили столь часто, что Р. Борден не мог выбрать время, чтобы посетить доминион. Действительно, за 18 месяцев работы (декабрь 1916 - июнь 1918 г.) «малый» военный кабинет, имперский военный кабинет и конференция провели в общей сложности 555 заседаний за 474 дня, исключая воскресные дни [9, p. 267].

В июле 1918 г. стало известно, что глава правительства Канады вынужден был остаться в Англии еще на некоторое время. Дело в том, что после формального закрытия второй сессии, заседания министров в формате имперского кабинета продолжались еще до 16 августа 1918 года. Необходимость в дополнительных встречах была вызвана событиями весенне-летнего наступления немцев на Западном фронте, активизировавших свои действия до прибытия американских батальонов во Францию [11, p. 8]. Оценивая положение союзных войск как критическое, Д. Ллойд Джордж завил, что лучше бы доминионы «производили меньше стали, угля и текстиля, а увеличили численность нашей армии». По его подсчетам, Канада за все время должна была отправить на фронт не менее 1 млн 200 тыс., а Австралия - 800 тыс. солдат. Такие рассуждения вызвали возражения со стороны колониальных делегатов. Р. Борден заметил, что, на его взгляд, данное замечание было несправедливым, поскольку в Канаде проживало значительное количество ненатурализированных нейтральных лиц, которых нельзя было принудительно завербовать. «Пусть Соединенные Штаты Америки наберут 6 млн человек, добавил он, и когда они это сделают, мы рассмотрим возможность отправить больше людей». В свою очередь, премьер-министр Австралии У. Хьюз заметил, что, «если мы выиграем войну и истечем кровью, это будет равносильно поражению» [11, p. 10-11]. 
По требованию главы британского правительства Р. Борден вновь отправился в Лондон в ноябре 1918 г., чтобы присутствовать на третьей сессии имперского военного кабинета. На повестке дня стояли вопросы мирного урегулирования, в том числе определение позиции британской делегации на переговорах в Париже [13, p. 4]. На этот раз канадским министрам были выделены отдельные кабинеты в Уайтхолле, где они работали над проблемами послевоенного урегулирования: У. Фостер занимался вопросами торговли, К. Сифтон и Э. Кемп - кораблестроением, иммиграцией и транспортом, Ч. Дохерти конституционными вопросами [15].

Британское руководство столкнулось с проблемой представительства доминионов на мирной конференции. 31 декабря 1918 г. состоялось последнее заседание кабинета, где Р. Борден изложил согласованный всеми доминионами «проект представительства». Британская делегация, как подчеркнул премьерминистр, должна была олицетворять не только Великобританию, но всю империю. Он считал необходимым «удовлетворить национальный дух канадского народа», предупредив, что «в противном случае возможно возникновение неблагоприятных и даже опасных последствий». Нестандартная обстановка требовала, по мнению Р. Бордена, принятия нестандартных решений. Именно поэтому он настаивал на праве каждого доминиона иметь, подобно малым союзным державам, отдельное представительство. Признание за государствами, не принимавшими активного участия в войне, например за Грецией и Португалией, возможности самостоятельно участвовать в процессе мирного урегулирования и лишение такого права Канады и Австралии, отдавших борьбе все силы, Р. Борден отказывался расценивать иначе, как верх несправедливости. В итоге была достигнута договоренность о двойном статусе доминионов и Индии как членов имперской делегации и как самостоятельных участников конференции [10, p. $8 ; 1$, с. 254-255]. На практике это означало преобразование имперского военного кабинета в делегацию Британской империи.

Результаты. Формирование системы единого военного управления Британской империей в годы Первой мировой войны явилось важным и закономерным итогом развития внутриимперских отношений, в котором в равной степени были заинтересованы как метрополия, так и доминионы. Британские власти, создавая такие площадки для дискуссий, преследовали несколько целей. Во-первых, они намеревались зафиксировать притязания доминионов, стремившихся изменить свой конституционный и функциональный статус в составе империи. Во-вторых, следовало определить обязательства доминионов в сфере военного взаимодействия для более успешного ведения войны. Для этого необходимо было познакомить лидеров самоуправлявшихся колоний с текущими проблемами международной жизни и реальной обстановкой, сложившейся на фронте. Наконец, предстояло определить место и роль доминионов в процессе разработки планов послевоенного мирного урегулирования.

Суммируя позицию Канады по важнейшим решениям имперского военного кабинета и конференций, следует отметить, что она была нацелена на укрепление автономного статуса доминиона в составе Британской империи. Война предоставила объективную возможность продемонстрировать метрополии и всему миру, что за последние полвека Канада из британской заморской территории превратилась в сильное государство с оформившейся национальной идентичностью и политическим самосознанием. Для упрочения своего положения в империи она должна была внести весомый вклад в победу Великобритании и союзников в войне. Для этого ей следовало отправить на фронт как можно больше солдат, что влекло за собой переход от добровольной системы набора к всеобщей воинской повинности. В качестве ответного шага после окончания войны метрополия должна была пересмотреть взаимоотношения со своими заморскими территориями, подтвердив их равный статус в структуре британского Содружества наций. Канада была готова к перенастройке конституционных отношений, направленной на трансформацию внутренних и внешних полномочий субъектов, входивших в состав империи. Для этого она требовала, во-первых, официального признания доминионов и Индии равными и независимыми нациями в составе Содружества; во-вторых, права самостоятельного участия во 
внешней политике Британской империи и в международных отношениях; в-третьих, участия в процессе выработки единой схемы военно-морской обороны империи с перспективой строительства собственного флота. Эти изменения были призваны завершить эволюцию правового и политического статуса Североамериканского доминиона в структуре империи и превратить его в полноправного члена британского Содружества наций.

\section{СПИСОК ЛИТЕРАТУРЫ}

1. Грудзинский, В. В. На повороте судьбы: Великая Британия и имперский федерализм (последняя треть XIX - первая четверть XX в.) / В. В. Грудзинский. - Челябинск : Челябин. гос. ун-т, 1996. $-312 \mathrm{c}$.

2. Ллойд Джордж, Д. Военные мемуары / Д. Ллойд Джордж ; пер. с англ. И. Звавича ; с предисл. Ф. А. Ротштейна. - Т. 4. - М. : Соцэкгиз, 1935. $-444 \mathrm{c}$

3. Brown, R. C. Robert Borden: a Biography / R. C. Brown. - Toronto : Macmillan of Canada, 1975.$148 \mathrm{p}$.

4. Commons Sitting of 22 January $1917 / /$ Official Reports of the Debates of the House of Commons of the Dominion of Canada, $12^{\text {th }}$ Parliament, $7^{\text {th }}$ Session, 1917. - Vol. 1 (Vol. CXXVI). - P. 7-45.

5. Commons Sitting of 18 May 1917 // Official Reports of the Debates of the House of Commons of the Dominion of Canada, $12^{\text {th }}$ Parliament, $7^{\text {th }}$ Session, 1917. - Vol. 2 (Vol. CXXVII). - P. 1523-1568.

6. Imperial War Conference, London, 1917. Extracts from Minutes of Proceedings and Papers Laid before the Conference. - London : Published by H.M.S.O., 1917. $-163 \mathrm{p}$.

7. Imperial War Conference, London, 1918. Extracts from Minutes of Proceedings and Papers Laid before the Conference. - London : Published by H.M.S.O., 1918. $-252 \mathrm{p}$.

8. Keith, A. B. War Government of the British Dominions / A. B. Keith. - Oxford : At the Clarendon Press, 1921. $-354 \mathrm{p}$.

9. Lords Sitting of 19 June 1918 // Official Hansard. Series 5. - Vol. 30. - Great Britain. House of Lords. - P. 239-288.

10. Minutes of a Meeting of the Imperial War Cabinet, December 31, 1918 // Imperial War Cabinet 1918. Minutes of Meetings, 30-48, August 13 December 31, 1918. - London : Printed at the Foreign Office by C. R. Harrison, 1918. - P. 1-21.

11. Minutes of a Meeting, August 16, 1918// Imperial War Cabinet 1917-1918, Committee of Prime Ministers,
Notes of Meetings, June 21 - August 16, 1918. London : Printed at the Foreign Office by C. R. Harrison, 1918. - P. 1-8.

12. Minutes of Meeting of 30 March, 1917 // Imperial War Cabinet 1917. Minutes of Meetings, 1-14, March 20 - May 2, 1917. - London : Printed at the Foreign Office by C. R. Harrison, 1917. - P. 1-8.

13. Minutes of the Thirty-Seventh Meeting of the Imperial War Cabinet, November 20, 1918 // Imperial War Cabinet 1918. Minutes of Meetings, 30-48, August 13 - December 31, 1918. - London : Printed at the Foreign Office by C. R. Harrison, 1918. P. 1-7.

14. Minutes of the Twenty-Sixth Meeting of the Imperial War Cabinet, July 23, 1918 // Imperial War Cabinet 1918 Minutes of Meetings, 15-29, June 11 August 2, 1918. - London : Printed at the Foreign Office by C. R. Harrison, 1918. - P. 1-7.

15. Premier Borden and Ministers Busily Engaged // Edmonton Bulletin. - 1918. - November 20 - - P. 1 .

16. Premiers Reach London, Imperial War Cabinet and Conference Soon to Assemble // New York Times. - 1918. - June 8. - P. 9.

17. Process-verbal of the First Meeting of the Imperial War Cabinet, March 20, 1917 // Imperial War Cabinet 1917-1918, Committee of Prime Ministers, Notes of Meetings, March 20, 1917 - November 28, 1918. - London : Printed at the Foreign Office by C.R. Harrison, 1918. - P. 1-13.

18. Soward, F. H. Sir Robert Borden and Canada's External Policy, 1911-1920 / F. H. Soward // Report of the Annual Meeting of the Canadian Historical Association. - 1941. - Vol. 20, № 1. - P. 65-82.

19. The Canadian Annual Review, War Series, 1917 / ed. by J. Castell Hopkins. - Vol. 17. - Toronto : Canadian Annual Review Limited, 1918. - 949 p.

20. The Canadian Annual Review, War Series, 1918 / ed. by J. Castell Hopkins. - Vol. 18. - Toronto : Canadian Annual Review Limited, 1919. - 879 p.

21. The War Conference of the Empire // The Round Table. A Quarterly Review of the Politics of the British Empire. - 1917. - Vol. 7, № 26. - P. 218-252.

22. War Cabinet, Report for the year 1917. London : Published by HMSO, 1918. - $236 \mathrm{p}$.

23. Wrong, G. M. Canada and the Imperial War Cabinet / G. M. Wrong // The Canadian Historical Review. - 1920. - Vol. 1, № 1. - P. 3-25.

\section{REFERENCES}

1. Grudzinskij V.V. Na povorote sud'by: Velikaja Britanija i imperskij federalizm (poslednjaja tret' $X I X$ - pervaja chetvert' $X X v$ v.) [At the Turn of Fate: Great Britain and Imperial Federalism (The Last Third of the $19^{\text {th }}$ - The First Quarter of the $20^{\text {th }}$ Centuries)]. 
Chelyabinsk, Chelyabinskiy gosudarstvennyy universitet, 1996. 312 p.

2. Lloyd George D. Voennye memuary [War Memoirs]. Vol. 4. Moscow, Sotsekgiz, 1935. 444 p.

3. Brown R.C. Robert Borden: A Biography. Toronto, Macmillan of Canada, 1975. $148 \mathrm{p}$.

4. Commons Sitting of 22 January 1917. Official Reports of the Debates of the House of Commons of the Dominion of Canada, $12^{\text {th }}$ Parliament, $7^{\text {th }}$ Session, 1917, vol. 1 (vol. CXXVI), pp. 7-45.

5. Commons Sitting of 18 May 1917. Official Reports of the Debates of the House of Commons of the Dominion of Canada, $12^{\text {th }}$ Parliament, $7^{\text {th }}$ Session, 1917, vol. 2 (vol. CXXVII), pp. 1523-1568.

6. Imperial War Conference, London, 1917. Extracts from Minutes of Proceedings and Papers Laid Before the Conference. London, Published by H.M.S.O., 1917. 163 p.

7. Imperial War Conference, London, 1918. Extracts from Minutes of Proceedings and Papers Laid Before the Conference. London, Published by H.M.S.O., 1918.252 p.

8. Keith A.B. War Government of the British Dominions. Oxford, At the Clarendon Press, 1921. $354 \mathrm{p}$.

9. Lords Sitting of 19 June 1918. Official Hansard. Series 5. Vol. 30. Great Britain. House of Lords, pp. 239-288.

10. Minutes of a Meeting of the Imperial War Cabinet, December 31, 1918. Imperial War Cabinet 1918. Minutes of Meetings, 30-48, August 13 December 31, 1918. London, Printed at the Foreign Office by C. R. Harrison, 1918, pp. 1-21.

11. Minutes of a Meeting, August 16, 1918. Imperial War Cabinet 1917-1918, Committee of Prime Ministers, Notes of Meetings, June 21 - August 16, 1918. London, Printed at the Foreign Office by C.R. Harrison, 1918, pp. 1-8.

12. Minutes of Meeting of 30 March, 1917. Imperial War Cabinet 1917. Minutes of Meetings, 1 -
14, March 20-May 2, 1917. London, Printed at the Foreign Office by C. R. Harrison, 1917, pp. 1-8.

13. Minutes of the Thirty-Seventh Meeting of the Imperial War Cabinet, November 20, 1918. Imperial War Cabinet 1918. Minutes of Meetings, 30-48, August 13 -December 31, 1918. London, Printed at the Foreign Office by C. R. Harrison, 1918, pp. 1-7.

14. Minutes of the Twenty-Sixth Meeting of the Imperial War Cabinet, July 23, 1918. Imperial War Cabinet 1918 Minutes of Meetings, 15-29, June $11-$ August 2, 1918. London, Printed at the Foreign Office by C.R. Harrison, 1918, pp. 1-7.

15. Premier Borden and Ministers Busily Engaged. Edmonton Bulletin, 1918, November 20, p. 1.

16. Premiers Reach London, Imperial War Cabinet and Conference Soon to Assemble. New York Times, 1918, June 8, p. 9.

17. Process-Verbal of the First Meeting of the Imperial War Cabinet, March 20, 1917. Imperial War Cabinet 19171918, Committee of Prime Ministers, Notes of Meetings, March 20, 1917 - November 28, 1918. London, Printed at the Foreign Office by C. R. Harrison, 1918, pp. 1-13.

18. Soward F.H. Sir Robert Borden and Canada's External Policy, 1911-1920. Report of the Annual Meeting of the Canadian Historical Association, 1941, vol. 20 , no. 1 , pp. 65-82.

19. Castell Hopkins J., ed. The Canadian Annual Review, War Series, 1917. Vol. 17. Toronto, Canadian Annual Review Limited, 1918.949 p.

20. Castell Hopkins J., ed. The Canadian Annual Review, War Series, 1918. Vol. 18. Toronto, Canadian Annual Review Limited, 1919.879 p.

21. The War Conference of the Empire. The Round Table. A Quarterly Review of the Politics of the British Empire, 1917, vol. 7, no. 26, pp. 218-252.

22. War Cabinet, Report for the Year 1917. London, Published by HMSO, 1918. 236 p.

23. Wrong G.M. Canada and the Imperial War Cabinet. The Canadian Historical Review, 1920, vol. 1, no. 1, pp. 3-25.

\section{Information About the Author}

Ekaterina S. Simonenko, Candidate of Sciences (History), Associate Professor, Department of Historical Education, School of Education, Far Eastern Federal University (FEFU), Sukhanova St, 8, 690091 Vladivostok, Russian Federation, eka-1982.82@mail.ru, https://orcid.org/0000-0001-7329-5346

\section{Информация об авторе}

Екатерина Сергеевна Симоненко, кандидат исторических наук, доцент кафедры исторического образования, Школа педагогики, Дальневосточный федеральный университет, ул. Суханова, 8, 690091 г. Владивосток, Российская Федерация, eka-1982.82@mail.ru, https:/orcid.org/0000-0001-7329-5346 